\title{
Coupling limit equilibrium analyses and real-time monitoring to refine a landslide surveillance system in Calabria (southern Italy)
}

\author{
G. G. R. Iovine ${ }^{1}$, P. Lollino ${ }^{2}$, S. L. Gariano ${ }^{1}$, and O. G. Terranova ${ }^{1}$ \\ ${ }^{1}$ CNR-IRPI, Rende-Cosenza, Italia \\ ${ }^{2}$ CNR-IRPI, Bari, Italia
}

Received: 18 March 2010 - Accepted: 25 July 2010 - Published: 22 November 2010

\begin{abstract}
On 28 January 2009, a large debris slide was triggered by prolonged rainfalls at the southern suburbs of San Benedetto Ullano (Northern Calabria). The slope movement affected fractured and weathered migmatitic gneiss and biotitic schist, and included a pre-existing landslide. A detailed geomorphologic field survey, carried out during the whole phase of mobilization, allowed to recognize the evolution of the phenomenon. A set of datum points was located along the borders of the landslide and frequent hand-made measurements of surface displacements were performed. Since 11 February, a basic real-time monitoring system of meteoric parameters and of surface displacements, measured by means of high-precision extensometers, was also implemented.

Based on the data gained through the monitoring system, and on field surveying, a basic support system for emergency management could be defined since the first phases of activation of the phenomenon. The evolution of the landslide was monitored during the following months: as a consequence, evidence of retrogressive distribution could be recognized, with initial activation in the middle sector of the slope, where new temporary springs were observed. During early May, the activity reduced to displacements of a few millimetres per month and the geo-hydrological crisis seemed to be concluded.

Afterwards, the geological scheme of the slope was refined based on the data collected through a set of explorative boreholes, equipped with inclinometers and piezometers: according to the stratigraphic and inclinometric data, the depth of the mobilized body resulted in varying between 15 and $35 \mathrm{~m}$
\end{abstract}

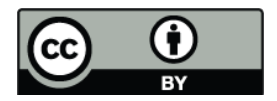

Correspondence to: P. Lollino (p.lollino@ba.irpi.cnr.it) along a longitudinal section. A parametric limit equilibrium analysis was carried out to explore the stability conditions of the slope affected by the landslide as well as to quantify the role of the water table in destabilizing the slope. The interpretation of the process based on field observations was confirmed by the limit equilibrium analysis: the first activation of the landslide was, in fact, to be expected in the middle portion of the slope, provided that the groundwater levels approximate the ground surface in the same sector.

On 1 February 2010, another remarkable phase of landslide mobilization began, following a new period of exceptional and prolonged rainfalls. On 11 February, an abrupt stage of slope acceleration was observed, after further extraordinary rainfalls. The slope movement essentially replicated the phases of mobilization observed on 28 January 2009, thus confirming the results of the limit equilibrium analysis. Based on the outcomes of the parametric analysis, the support system for emergency management could then be tentatively refined on a more physical basis.

\section{Introduction}

A large part of Italy is threatened by slope movements that, in some cases, severely interfere with the urbanized environment (Guzzetti, 2000). Due to either scarcity of funds, technical reasons (e.g., lack of safer places where the villages at risk could be relocated), or even because inhabitants generally refuse to transfer from their original places, the only practicable option is coexistence with the risk. In such cases, suitable actions must be adopted in terms of mitigation and/or reduction of the risk, once the type and extent of the instability phenomena have properly been recognised

Published by Copernicus Publications on behalf of the European Geosciences Union. 
and the related causal factors have been understood through detailed field investigations, interpretation of available data sources (e.g., air-photos, in situ tests, laboratory) and calculation techniques.

Unfortunately, some types of slope movements (e.g., soil slip, debris flow, rock fall) are characterised by sudden activations, with few precursory signs, and move rapidly with high-destructive capacity. Moreover, the exact location of their source areas is difficult to forecast - even though the geomorphological contexts prone to such types of instabilities are generally well known. On the other hand, larger phenomena (e.g., rock/earth slide, earth flow) usually affect the same zone repeatedly: short-lasting phases of mobilizations are commonly triggered by external causes (like heavy rainfalls or earthquakes) and may give rise to quite limited displacements; sometimes, the area involved in a landslide reactivation results remarkably enlarged. In all these cases, the mitigation approach may effectively help to manage the risk (cf. Campbell, 1975; Dai et al., 2002).

When dealing with the potential reactivation of a large slope movement threatening an urbanized area, risk mitigation can be essentially based, in the short-term, on a combination of: (i) innovative monitoring techniques of the main controlling factors, (ii) in situ real-time data collection and transfer to a processing centre, and (iii) mathematical modelling. In this way, a deeper knowledge of the phenomenon can be acquired, as a propaedeutic basis for properly approaching risk reduction through stabilisation and protection works and for improving urban planning (Anderson et al., 2008).

To this purpose, useful relationships among measurable causal factors and the behaviour of a given phenomenon of interest can be defined. A reliable model for predicting both the triggering mechanism and the evolution of the landslide may also be implemented, based on data gathered through a reliable monitoring system of the most significant controlling factors (e.g., rainfalls, groundwater levels, displacements at surface and at depth).

Because slope instability may develop at short notice, it becomes fundamental to adopt techniques capable of promptly revealing warning signs (cf. Ramesh, 2009). Realtime systems of data acquisition and transfer via GSM seem to be the most appropriate ones when cable transmissions are impracticable or cannot be adopted (e.g., due to economic constraints). Consequently, by transferring the collected data to a processing station, a suitable support system for emergency management can be implemented.

In the present paper, the mobilization of the San Rocco landslide at San Benedetto Ullano (Northern Calabria) is analysed by considering field and real-time monitoring data, and by parametric limit equilibrium calculations. The slope movement was first triggered by prolonged rainfalls on January 2009 and went on with significant displacement rates for three months, threatening the southern margin of the village and damaging the major transportation infrastructures
(Iovine et al., 2009). Afterwards, the landslide remained dormant (or showed very-slow localized movements) during the following eight months. A new phase of activation started on February 2010, again after extraordinary rainfalls: as already occurred on previous activation, the slope movement started in the middle sector of the slope, where the groundwater levels reached the slope surface, and progressively extended in the following weeks, causing serious damage to infrastructures.

An empirical approach was adopted to support the local Authority of Civil Protection since the very-early phases of the geo-hydrological crisis. A set of simplified procedures was defined to verify the evolutive conditions of the phenomenon in the field, by testing suitable indicators. In addition, rainfalls and surface displacements were also monitored via a basic real-time system. Finally, the geological scheme of the slope was refined by means of a set of explorative boreholes equipped with inclinometers and piezometers.

The stages of activation of the San Rocco landslide, occurred in 2009 and 2010, are described. Since the available data refer to a limited observation period, the limit equilibrium analyses were performed in terms of parametric calculations with respect to water table variations. The results are consistent with the field observations made during the critical stages of the landslide mobilization and highlight the role of the groundwater level variations in destabilizing the considered instability process.

\section{The study area}

The slope movement affected the San Rocco area, south of the historical centre of San Benedetto Ullano (SBU). The site is located in the northern portion of the Calabrian Arc, on the left flank of the Crati graben (Fig. 1a). The Arc is an accretionary wedge made of a series of Jurassic to Early Cretaceous ophiolite-bearing tectonic units, plus overlying Hercynian and pre-Hercynian basement nappes (Amodio-Morelli et al., 1976). In Oligocene-Early Miocene, these units were emplaced on the Mesozoic of the Apennine Chain. Since Middle Miocene, overthrusting and the progressive migration of the Calabrian Arc towards the southeast combined with the opening of the Tyrrhenian basin. Strike-slip tectonics mainly characterised the tectonic framework from Late Miocene to Quaternary (Tansi et al., 2007). In Late PlioceneEarly Quaternary, the Arc was dissected by normal faults. Since Middle Pleistocene, a regional WNW-ESE oriented extensional phase occurred, resulting in the "Calabrian-Sicilian rift-zone" (Monaco and Tortorici, 2000) - whose northern portion corresponds to the cited Crati graben - coupled with a strong regional uplifting.

As a consequence, the rock units of the Calabrian Arc are commonly characterised by pervasive systems of fractures. Such a situation favoured the development of severe weathering processes in metamorphic and crystalline 


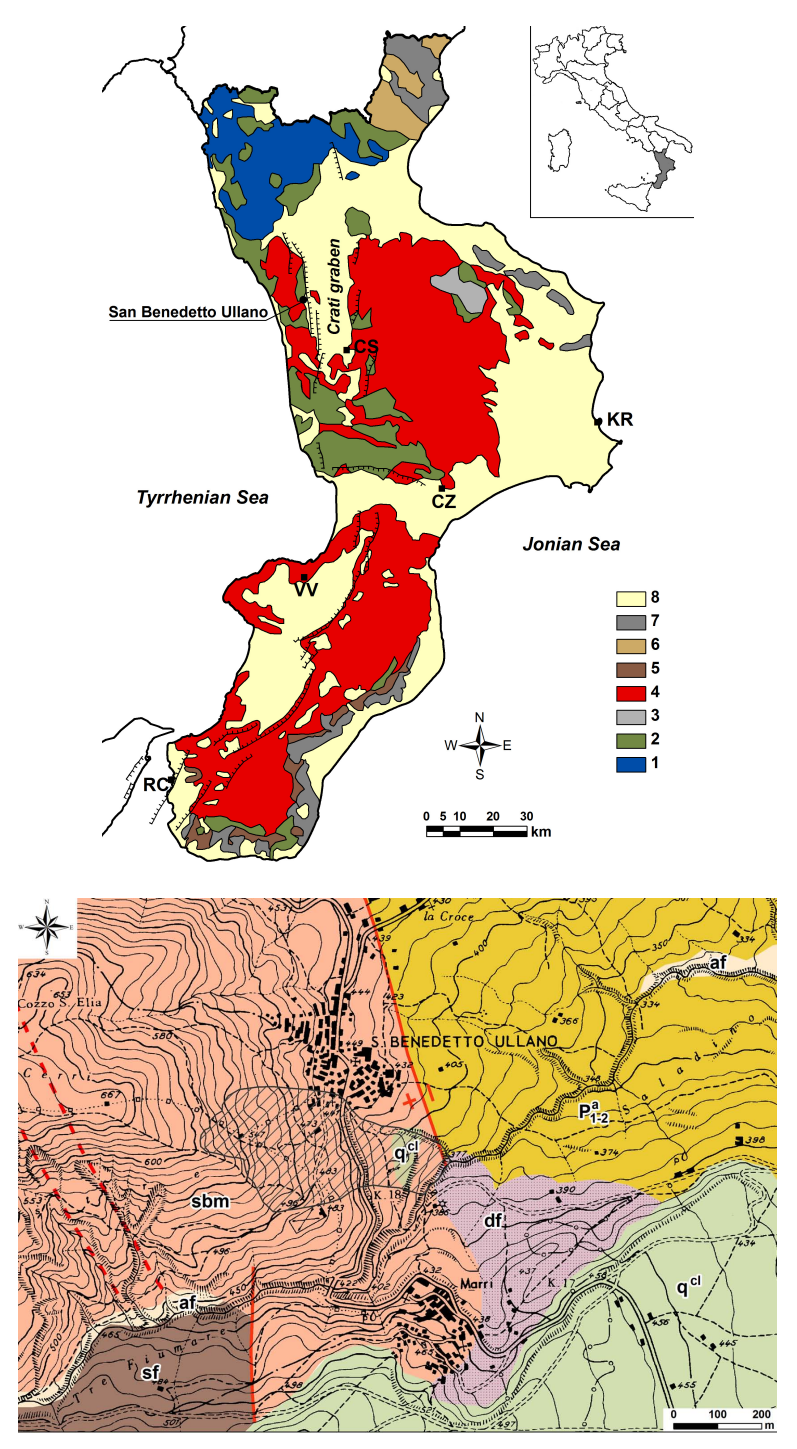

Fig. 1. (a) Location of the study area and main lithological complexes of Calabria (after Sorriso-Valvo, 1993, mod.). Key: (1) carbonate units; (2) very low to low-grade metamorphic units, at places with ophiolites; (3) sedimentary, flysch-type sequence; (4) intermediate to high-grade metamorphic and intrusive rocks; (5) turbiditic, mainly coarse-grained deposits; (6) flysch-type nappes, mainly marley-clayey; (7) flysch-type nappes, with chaotic structure; (8) sedimentary autochthonous units; CS) Cosenza; CZ) Catanzaro; KR) Crotone; RC) Reggio di Calabria; VV) Vibo Valentia. In black, the main tectonic structures belonging to the Calabrian-Sicilian Rift Zone (after Monaco and Tortorici, 2000, mod.) are also shown. (b) Geological map of the study area, after CASMEZ (1967), modified. Key: (af) alluvial sediments (Holocene); (df) landslide debris (Holocene); $\left(\mathrm{q}^{\mathrm{cl}}\right)$ loose conglomerate of ancient fluvial terraces (Pleistocene); $\left(\mathrm{P}_{1-2}^{\mathrm{a}}\right)$ grey-blue silty clay (Middle-Late Pliocene); ( $\mathrm{sbm}$ ) gneiss and biotitic schist with garnet, locally including abundant granite and pegmatite veins, forming migmatite zones (Palaeozoic); (sf) grey phyllitic schist, with rare intercalations of limestone and arenite, and quartz veins (Palaeozoic). The area shaded in black delimits the sector threatened by the San Rocco landslide. In the figure, the road to the cemetery, the church of S. Rocco, and the provincial road to Marri (SP.31) are also shown.

www.nat-hazards-earth-syst-sci.net/10/2341/2010/ terranes (Guzzetta, 1974). The combined effect of severe tectonic disturbance, differentiated uplift, physical-chemical weathering and erosional processes determined the actual physiographic setting, and permitted the development of widespread slope movements of different type and extent.

Meteoric events together with earthquakes represent the main triggering factors of slope movements in Calabria (Sorriso-Valvo, 1985). The latter pose serious risk conditions in many parts of the region (cf. e.g., Carrara et al., 1977, 1979; Sorriso-Valvo, 1985; Crescenzi et al., 1996; Iovine and Merenda, 1996; Iovine et al., 1996; Iovine and Petrucci, 1998; Ferrari et al., 2000; Tansi et al., 2005).

San Benedetto Ullano lies at $450 \mathrm{~m}$ a.s.l. (Fig. 1b), at the base of the eastern flank of the Coastal Chain marking the left margin of the Crati graben. The area is crossed by a N-S trending normal fault, belonging to the CalabrianSicilian rift-zone, that extends for about $30 \mathrm{~km}$ from San Fili to San Marco Argentano. Along such a fault, the Palaeozoic metamorphic rocks (mostly gneiss, schist and phyllite) of the Coastal Chain, to the West, give place to PlioceneQuaternary sediments (mostly conglomerate, sand and clay) of the Crati graben, to the East (CASMEZ, 1967). Physiography strongly affects the climatic characteristics of the area, as described for distinct homogeneous zones by Versace et al. (1989): abundant yearly rainfalls are usually recorded in the surroundings of SBU, one of the most rainy places of the region. The mean annual and monthly rainfalls at the closest rain gauge, located at Montalto Uffugo (about $4 \mathrm{~km} \mathrm{SE}$ of SBU), are shown in Table 1.

\section{The San Rocco landslide}

\subsection{The 28 January 2009 activation}

During autumn-winter 2008/09, Calabria experienced severe storms, mostly concentrated from December to January; severe rains were recorded since November, and persisted until the end of March. In the vicinity of SBU, cumulated rains from November to March exceeded more than twice the seasonal average; during the 2-3 months antecedent to the 2009 landslide mobilization, cumulated values were very close to the first two critical events ever recorded at Montalto Uffugo since 1921 (Iovine et al., 2009). Rainfalls exceeding $500 \mathrm{~mm}$ were recorded in the last 10 days before landslide activation. By comparing either the historical maxima (period 1921-2006) of the rainfalls cumulated over 30-60-90120 days (Fig. 2a), or the monthly averages (Fig. 2b), with the rains recorded during the autumn-winter 2008/09, these latter exceed the maxima for aggregations of 74 days and longer, with monthly rains remarkably greater than mean values.

On 28 January 2009, a set of fissures was first noticed by the inhabitants along the road network, in the middle portion of the slope (Fig. 3). Since 5 February, due to further 
Table 1. Montalto Uffugo rain gauge (468 m a.s.1.). First row: 1921-2006 average values (mm); second row: 2008/09 values (mm); third row: autumn-winter 2009/10 values (mm). In bold, values greater than monthly averages.

\begin{tabular}{|c|c|c|c|c|c|c|c|c|c|c|c|c|c|}
\hline & Sep & Oct & Nov & Dec & Jan & Feb & Mar & Apr & May & Jun & Jul & Aug & year \\
\hline Average & 70.4 & 125.1 & 187.9 & 220.8 & 198.1 & 160.3 & 132.8 & 98.9 & 64.6 & 27.8 & 18.3 & 28.6 & 1333.6 \\
\hline $2008 / 09$ & 174.8 & 89.0 & 216.6 & 524.4 & 647.8 & 335.6 & 417.0 & 142.5 & 26.4 & 77.8 & 0.4 & 0.0 & 2652.3 \\
\hline $2009 / 10$ & 141.0 & 247.6 & 129.6 & 350.2 & 575.2 & 351.0* & & & & & & & \\
\hline
\end{tabular}

* Amount recorded from 1 to 13 February 2010.

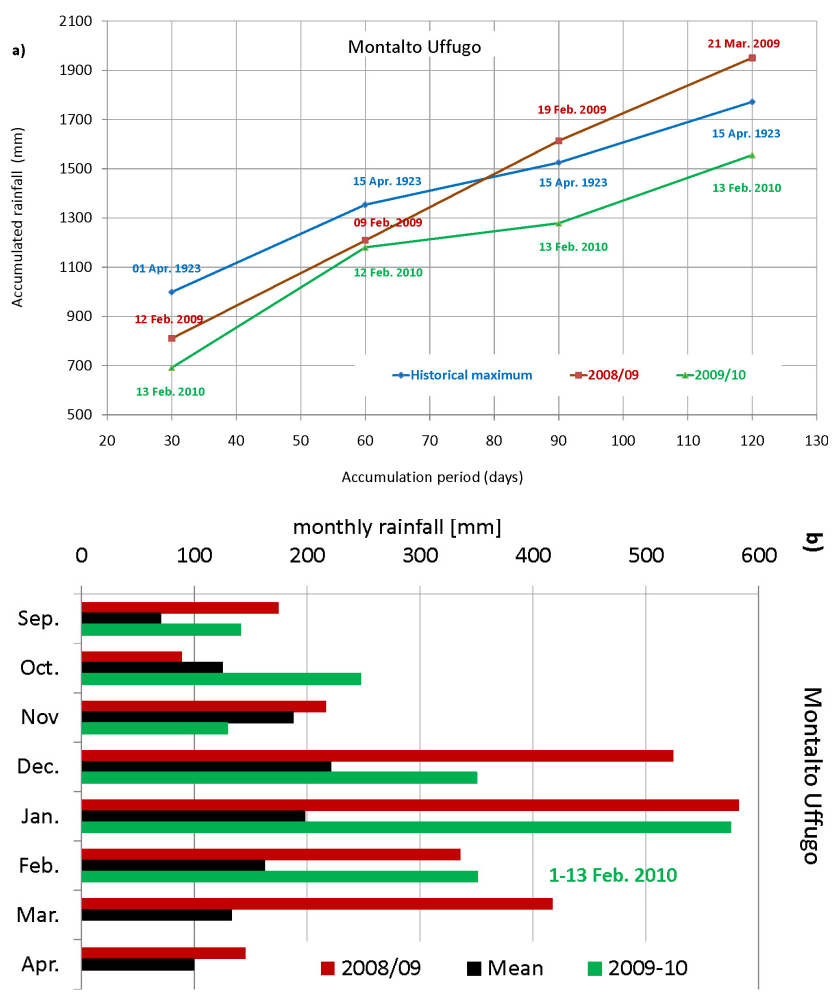

Fig. 2. Rains recorded during the 2008/09 and 2009/10 hydrological years, compared to (a) historical maxima (period 1921-2006), in terms of accumulated rains, and (b) monthly rainfalls.

precipitations, the phenomenon retrogressed into the woodland area: the main scarp developed just above the village (at about $590 \mathrm{~m}$ a.s.l.) at the eastern margin of the "Piano dei Cerri" (667 m a.s.l., cf. Fig. 1b). Fractures delimiting the left flank of the landslide opened very close to the San Rocco deconsecrated church, while the right flank skimmed the cemetery. The landslide foot threatened a private building located further downslope (cf. "P" in Fig. 3); fresh fractures also opened by the torrent Marri, presumably correlated to a minor earth slide. As a whole, the slope movement severely damaged the road to the cemetery and the provincial road (SP.31) to Marri. Following a moderate snowfall, which occurred on 13 February, scarp segments $40 \mathrm{~cm}$ high and $30 \mathrm{~m}$ long developed in the uppermost sector of the slope, arranged

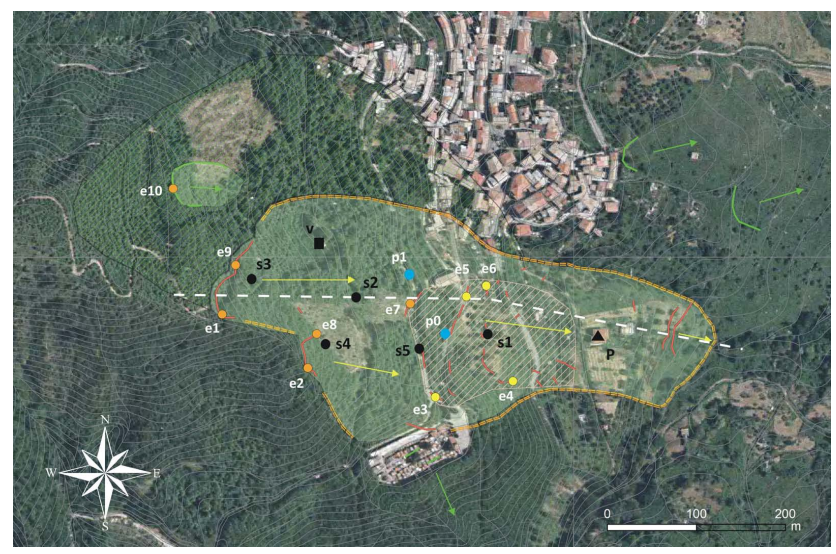

Fig. 3. Geomorphological scheme of the San Rocco slope movement (after Iovine et al., 2009, mod.). (Key) in red: main fractures opened during the first phase of mobilization (January-May 2009); green hatched area: ancient, inactive landslide; pink hatched area: portion of the landslide that showed the greatest evidence of mobilization on both activations, with opening of new springs; yellow arrows: average directions of displacement, as determined from field evidence; in green: fractures and directions of movement of other active gravitational phenomena; $\mathrm{S}_{1-5}$ : boreholes drilled in summer 2009 (black dots); $\mathrm{e}_{1-10}$ : extensometers ( $\mathrm{e}_{1-6}$ active since February 2009; e $3-6$ inactive since February 2010; e $_{7-10}$ active since February 2010); $\mathrm{p}_{0-1}$ : meteoric station (blue dots: $\mathrm{p}_{0}$ active from April 2009 to February 2010; $p_{1}$ active since March 2010); black triangle: the building "P"; black square: cistern of the water system ("v"); white dashed line) profile considered in the parametric analyses (cf. Figs. 10-14). A piezometer was installed in $S_{1}$; $\mathrm{S}_{2-5}$ were equipped with inclinometers. The threatened area is evidenced in light-green, and bordered with an orange dashed line.

into an irregular system of fractures. In the following weeks, fractures kept on widening and lengthening, and new ruptures opened outside the sector affected by the first slope instability.

Based on detailed geomorphologic field surveys, repeatedly carried out since the early stages of activation, the evolution of the phenomenon was progressively mapped, along with the area presumably affected (cf. Fig. 3). Since 31 January, a set of datum points was located over the landslide body and along its margins; their position was progressively adjusted during the following weeks in accordance with the 


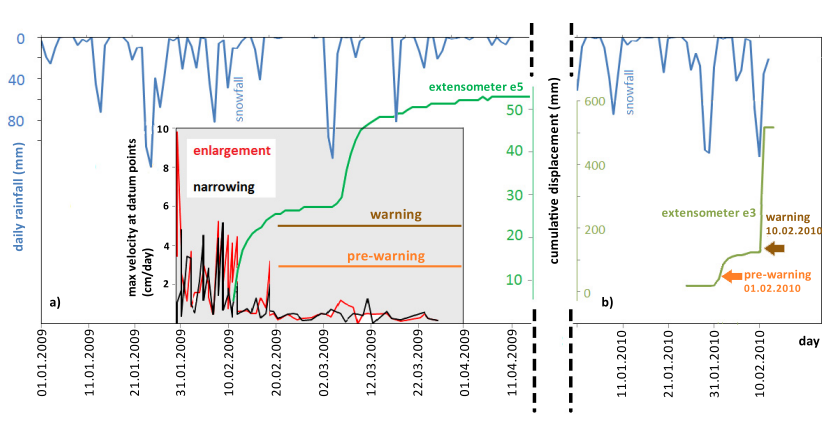

Fig. 4. Rainfalls and superficial displacements recorded at extensometers and datum points, during the 2009 (a) and 2010 (b) phases of mobilization. Key: (in blue) daily rain; (in black/red): maximum daily displacement rates at datum points; in green) cumulated displacements at the extensometers $\mathrm{e}_{5}$ and $\mathrm{e}_{3}$. The empirical, punctual velocity thresholds ( 3 and $5 \mathrm{~cm} / \mathrm{d}$ ), that were employed for managing the emergency, are also shown (after Iovine et al., 2009). Timing of pre-warning and warning conditions is indicated.

development of the phenomenon. The superficial kinematics of the phenomenon was monitored by means of frequent hand-made measurements of displacement at datum points, that were carried out by a team of technicians from the municipality. In the early stages of activation, rainfalls were obtained from the website of the ARPACAL regional agency (http://www.cfcalabria.it/). On 11 February, a weather station plus a set of precision-extensometers were also installed and a real-time system (ADs) of data collection and transfer via GSM was implemented. The frequency of measurements was set as a function of the observed values of the considered parameters.

The collected data allowed for the monitoring of the evolution of the phenomenon until evidence of negligible activity was observed. Displacements remained significant ( $\geq 1 \mathrm{~cm} / \mathrm{month}$ ) at two or more extensometers until 17 April; they persisted at only one extensometer until 4 May. The activity continued at smaller rates (few $\mathrm{mm} / \mathrm{month}$ ) during late spring to summer 2009, when the emergency was considered to be over. Even though characterised by a quite complex behaviour, daily displacements resulted to be generally consistent among themselves, showing a clear relationship with rainfalls, with quasi-immediate responses (about $12-$ $24 \mathrm{~h}$ ) for rains exceeding $30 \mathrm{~mm} /$ day (Fig. $4 \mathrm{a}$ ).

During the phase of mobilization, new temporary springs were observed, even inside some buildings, whereas preexisting springs showed a notable increase of flow rate at several locations on the landslide body and in the surroundings. In the middle portion of the slope, the water table progressively intercepted the ground surface. Apparently, the stability conditions of the slope had to remain quite precarious even during the stages of intermittent quiescence. Certainly, infiltration of rainfall was favoured by the high permeability of the detrital cover and by the fractures opened due to landslide displacement, thus favouring the rapid raising of the water table.
Further insights on the type of material, the variations of groundwater level with time and the slope displacements at depth were derived from the results of five explorative boreholes, which were drilled between May and July 2009 and equipped with one open-pipe piezometer and four inclinometers. Based on such information - as well as on the spatial distribution of the detected fractures, on their attitude and size, and on kinematic evidence - the surveyed features were interpreted as evidence of an individual, large slope movement.

The San Rocco landslide included a former inactive slope movement, as reported in the landslide risk map made by the regional Basin Authority (PAI, 2001). Moreover, the phenomenon - at least in its middle portion - represents a partial reactivation of a larger, inactive landslide affecting the whole slope above the historical centre (cf. Fig. 3). It mobilized a variable thickness $(15-35 \mathrm{~m})$ of mostly colluvial terrains, derived from fractured and weathered migmatitic gneiss and biotitic schist of the Coastal Chain. The ground evidence related to the rupture surfaces migrated with time from the middle portion of the slope laterally toward the flanks, upslope in the forest land and downslope of the cited building ("P" in Fig. 3). Based on the collected information, a schematic section of the slope could be drawn, as shown in Fig. 5 (see also Sect. 4).

Due to the lack of detailed knowledge of the phenomenon, a preliminary empirical approach of risk management was adopted to support the Mayor since the first phases of emergency. The surveillance system was based on detailed geomorphologic field surveys combined with cross-analyses of hydrologic data and of surface displacements - as summarized in Table 2 and described by Iovine et al. (2009). The management of the emergency took advantage of the ADs, which provided timely information for activating the procedures during all the phases of the phenomenon. Procedures were mainly based on the rate of measured displacements at surface, in addition to daily rainfalls and other evidence of slope evolution. They were devised by considering thresholds for daily maximum velocities at selected sites, as suggested by the literature (cf. Oboni, 1988, reviewing the studies by Azimi et al. (1988); Salt (1988); Tran vo Nhiem et al. (1988); cf. Iovine et al. (2006), and references therein). The criteria for discriminating among alarm levels also took into account whether the observed evidence regarded one or more sites in the affected area. In accordance with the procedure described, distinct automated protocols were defined to inform the Mayor and the team of advisor experts in due time.

\subsection{The 1 February 2010 activation}

Between autumn and early winter 2009/10, a new phase of abundant precipitations occurred in Calabria. Again, the most affected zone resulted in being the inner side of the Coastal Chain: here, rainfalls twice the average were 


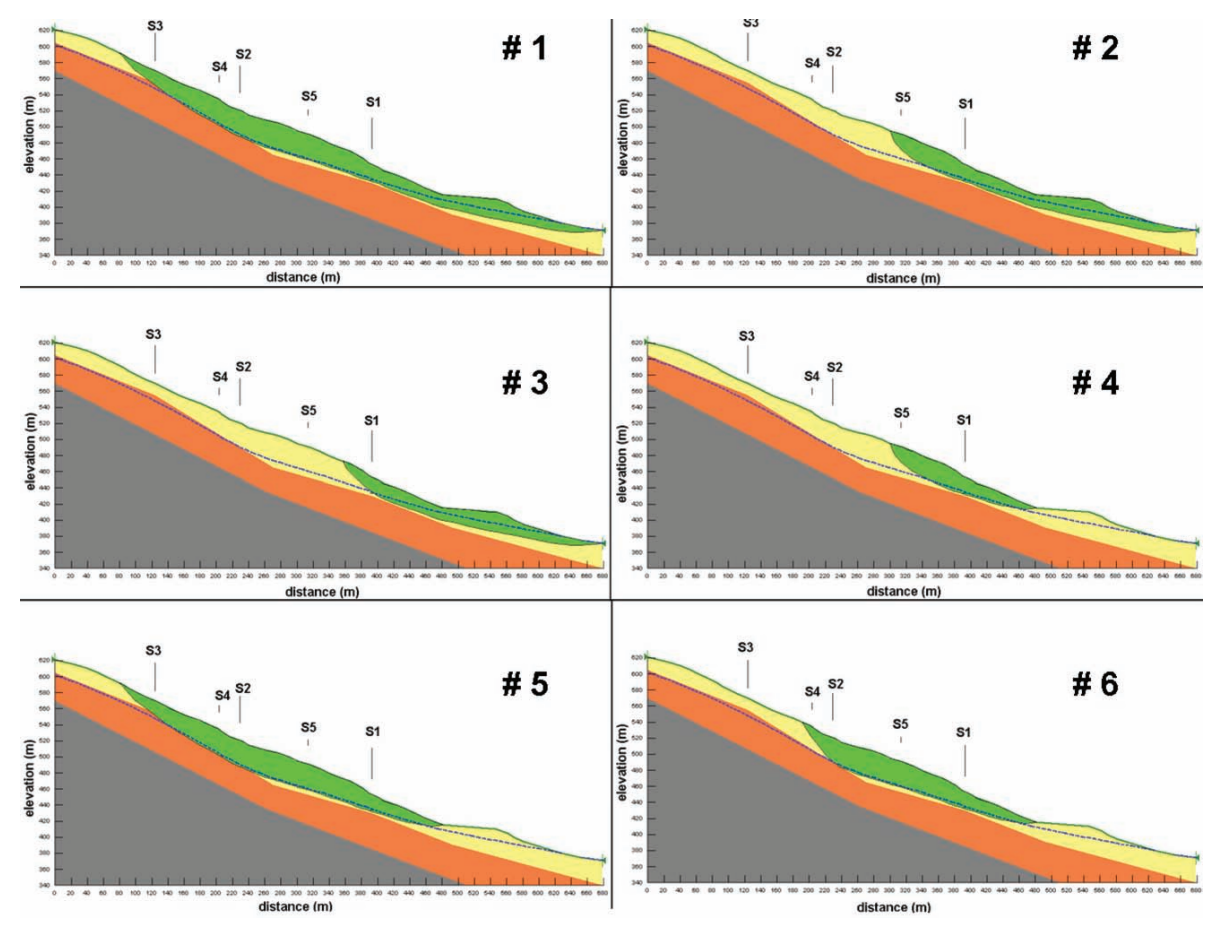

Fig. 5. Scheme of the slope adopted for the limit equilibrium back-analyses (see text for details). The considered three layers, the six main landslide bodies, and the locations of the boreholes are shown.

recorded in January, exceeding again the monthly average during the first 13 days of February. In particular, at Montalto Uffugo, a rainfall height of about $330 \mathrm{~mm}$ fell between 26 January and 1 February; after 5 more days, $320 \mathrm{~mm}$ were recorded between 6 and 13 February. It should be noticed that rainfalls recorded in September, October and December 2009 were even higher than the monthly averages (cf. Fig. 2).

Until January 2010, no remarkable evidence of activity had been recognized, neither during field surveys nor through the ADs, and only minor localized movements had been detected, generally following meteoric events (e.g., at the end of summer 2009, in the middle portion of the landslide area). Following extraordinary rainfalls (about $250 \mathrm{~mm}$ in 6 days), a new phase of activation started on 1 February 2010: the landslide mobilized again in the middle sector of the slope, between the municipal road to the cemetery and the SP.31. A new set of datum points was promptly defined, and daily measures were performed by municipal technicians.

After a further $295 \mathrm{~mm}$ of rainfall in 11 days, from 11 February, the middle portion of the landslide showed a phase of paroxysmal activation, which caused the failure of the main infrastructures crossing the unstable area (water system, gas pipeline, power line), and partly damaged the ADs (some of the instruments had to be relocated). Rapid movements were recorded on 12 February, when over $35 \mathrm{~mm}$ of additional rains fell coupled with a modest snowfall: serious damage was observed along the local roads and the
SP.31; new fissures opened at the toe of the slope movement, along the road to the building "P". In the same sector, the groundwater level reached the slope surface: temporary springs were observed, and the pre-existing ones showed an increased flow rate.

The extent of the affected area progressively increased in the following days: starting from 13 February, fractures and scarps opened even in the woodland area (corresponding to the main scarps already detected during the 2009 activation). Up to late February 2010 (when this manuscript was completed), the slope movement was still active.

With respect to the 2009 activation, the effects on the road network and infrastructures crossing the landslide body resulted in being, by far, more severe. Again, the activation started in the middle portion of the slope, where the groundwater intercepted the surface; the activity gradually extended outside the area first affected by the slope movement. In Fig. $4 \mathrm{~b}$, the cumulated and average rainfalls are shown, together with kinematic data regarding the 2010 landslide activation.

Based on the above cited surveillance system, even this phase of activation could be detected since its very beginning, and proper actions were promptly undertaken by the Mayor of SBU to mitigate the risk. 
Table 2. Basic emergency procedures of landslide-risk management implemented at SBU (after Iovine et al., 2009, mod.), with refinements in the adopted criterion based on LEM analyses (cf. second column, and Table 3 ). Thresholds of maximum punctual velocity ( $v$ ) are in $\mathrm{cm} /$ day. In Italics, instruments not available during the very-early phases of emergency in winter 2009 . In white characters, mitigation measures suggested to the Authority of Civil Protection.

\begin{tabular}{|c|c|c|}
\hline level of alarm & criterion & summary of suggested procedures \\
\hline normal & $\begin{array}{c}F_{i}>1.3 \\
\quad \text { or } \\
v<0.75\end{array}$ & $\begin{array}{l}\text { Occasional patrol of the affected area; measures at } \\
\text { datum points, inclinometers }{ }^{*} \text {, piezometers }{ }^{*} \text {, rain } \\
\text { gauges. }\end{array}$ \\
\hline
\end{tabular}

\begin{tabular}{|c|c|c|}
\hline pre-alert & $\begin{array}{c}1.2<F_{i} \leq 1.3 \\
\quad \text { or } \\
0.75 \leq v<1.5\end{array}$ & $\begin{array}{l}\text { Patrol of the affected area ( } 2-4 \text { times per month); } \\
\text { measures at datum points; monitoring via ADs, } \\
\text { inclinometers }{ }^{*} \text {, piezometers }\end{array}$ \\
\hline alert & $\begin{array}{l}1.1<F_{i} \leq 1.2 \\
\quad \text { or } \\
1.5 \leq v<3.0\end{array}$ & $\begin{array}{l}\text { Patrol of the affected area ( } 3-4 \text { times per week) to } \\
\text { recognize anomalous evidence of evolution; daily } \\
\text { measures at datum points, with immediate data } \\
\text { transmission; weekly patrol along the forest paths } \\
\text { and the water system; monitoring via ADs, } \\
\text { inclinometers", piezometers }\end{array}$ \\
\hline pre-warning & $\begin{array}{c}1.05<F_{i} \leq 1.1 \\
\text { or } \\
3.0 \leq v<5.0\end{array}$ & $\begin{array}{l}\text { Daily patrol of the affected area to recognize } \\
\text { dangerous evidence of evolution; } 1-2 \text { daily measures } \\
\text { at the datum points, with immediate data } \\
\text { transmission; patrol along the forest paths and the } \\
\text { water system (3-4 times per week); monitoring via } \\
\text { ADs, inclinometers }{ }^{*} \text {, piezometers } \\
\text { Pre-warning of inhabitants; closure of roads to traffic } \\
\text { during the night, and lighting of threatened streets } \\
\text { and buildings. }\end{array}$ \\
\hline warning & $\begin{array}{l}F_{i} \leq 1.05 \\
\quad \text { or } \\
5.0 \leq v\end{array}$ & $\begin{array}{l}\text { Daily patrol of the affected area to recognize } \\
\text { dangerous evidence of evolution; monitoring via } \\
\text { ADs, inclinometers }{ }^{*} \text {, piezometers }{ }^{*} \text {. } \\
\text { Warning to inhabitants; evacuation of people from } \\
\text { threatened buildings; closure of roads. }\end{array}$ \\
\hline
\end{tabular}

(*) if accessible/working

\section{Limit equilibrium parametric analysis}

A parametric back-analysis of the San Rocco landslide activations was performed by means of the limit equilibrium method (LEM). Such a widely used approach assumes the mass delimited by the sliding surface to be at "limit equilibrium" state when the soil shear failure is reached along the sliding surface (this corresponding to a factor of stability of the landslide body equal to unity). Although soil behaviour is schematized as rigid-perfectly plastic, LEM provides acceptable solutions in terms of the factor of stability of the slope in many practical problems (e.g., Duncan, 1992; Morgenstern, 1992; Fell et al., 2000). For those cases characterised by complex geometry, the calculation of the factor of stability is carried out by employing either approximated methods - as in Janbu (1954) and in Bishop (1955) simplified approaches - or rigorous methods - as in Morgenstern and Price (1965), Spencer (1967) and Sarma (1973) - the latter providing more accurate solutions. The main advantage of the LEM lies in the simplicity of implementation for practical purposes, whereas its main limitations are generally recognised in: (i) the need to assign an a priori geometry to the failure surface, and (ii) the assumptions regarding the soil behaviour and the stress state of the soil mass.
The analysis of the described activations of the San Rocco landslide was performed with the Morgenstern and Price (1965) method for the calculation of the factor of stability. As described below, a finite element analysis was preliminarily carried out to define the regime in the slope associated to steady-state summer flow conditions, to be implemented in the LEM analysis.

The stratigraphic scheme adopted for the calculation was assumed according to the borehole data, which essentially suggested a threefold partition of the underground stratigraphy. In Fig. 5, following the classification of the weathering degree proposed by Cascini et al. (1994), the yellow layer represents the detrital gneissic cover (classes VI and V), the orange layer represents the weathered bedrock (classes $\mathrm{V}$ to IV), and the grey layer represents the intact bedrock (classes III, II and I).

The landslide bodies considered in the LEM analysis are shown in Fig. 5. They were defined according to the available in situ geomorphological evidences (cf. Fig. 3), to borehole stratigraphic information and to inclinometer data (cf. Fig. 6). 


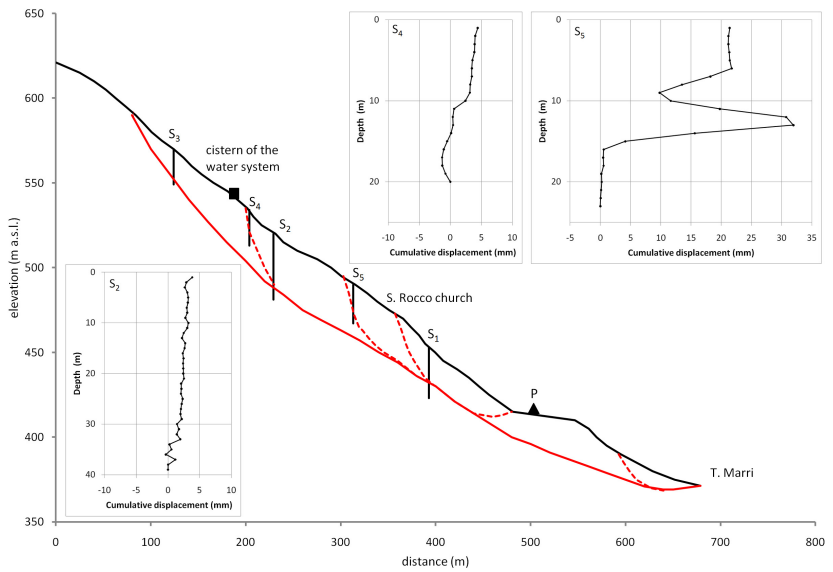

Fig. 6. San Rocco landslide: schematic section of the slope showing the different bodies considered for the limit equilibrium backanalyses. Location and depth of the boreholes, together with the main surfaces of rupture and the results of inclinometric measures (updated at December 2009) at boreholes $\mathrm{S}_{2}, \mathrm{~S}_{4}$ and $\mathrm{S}_{5}$ are also shown.

The sliding surfaces delimiting the landslide bodies \#1-3 were assumed to have the toe by the T. Marri (at $370 \mathrm{~m}$ a.s.1.); those related to the bodies \#4-6 have the toe at the convex break in slope located just upslope of the building "P" (at $415 \mathrm{~m}$ a.s.l).

The main scarp of the longest landslide body (\#1) was observed in the field at $590 \mathrm{~m}$ a.s.l.; moreover, the geometry of the basal surface of rupture is constrained by stratigraphic and inclinometric evidence (at $S_{1}$ and $S_{2}$, resp). The main scarp of the landslide body \#2 is located in the middle part of the slope (at $495 \mathrm{~m}$ a.s.1.); the basal surface of rupture is constrained by stratigraphic and inclinometric evidence (at $S_{1}$ and $S_{5}$, resp). The main scarp of the landslide body \#3 is located in the lower part of the slope (at $473 \mathrm{~m}$ a.s.l.); the basal surface of rupture is constrained by stratigraphic evidence (at $S_{1}$ ). The lowermost portion of the sliding surfaces delimiting the bodies \#1-3 is supposed to coincide, from the elevation of $430 \mathrm{~m}$ a.s.l. downwards. The landslide body \#4 corresponds to the slope portion that showed the greatest dislocations during the recent winter seasons; its main scarp coincides with that of landslide $\# 2$, and the basal surface of rupture is constrained by stratigraphic and inclinometric evidence (at $S_{1}$ and $S_{5}$, resp.). The landslide body \#5 differs from \#1 for the location of the toe of the surface of rupture, and then roughly coincides to its middle-upper portion. Finally, the landslide body \#6 has the main scarp at ca. $540 \mathrm{~m}$ a.s.l.; its basal surface of rupture is constrained by stratigraphic and inclinometric evidence (at $\mathrm{S}_{1}$ and $\mathrm{S}_{4}$, resp).

The physical and mechanical properties of the material were obtained from available identification tests, grain-size distribution data and direct shear tests, which were performed on samples taken down $\mathrm{S}_{3}$ and $\mathrm{S}_{4}$ boreholes at shallow depths, within the gneissic cover (Nicola Chiarelli, per-

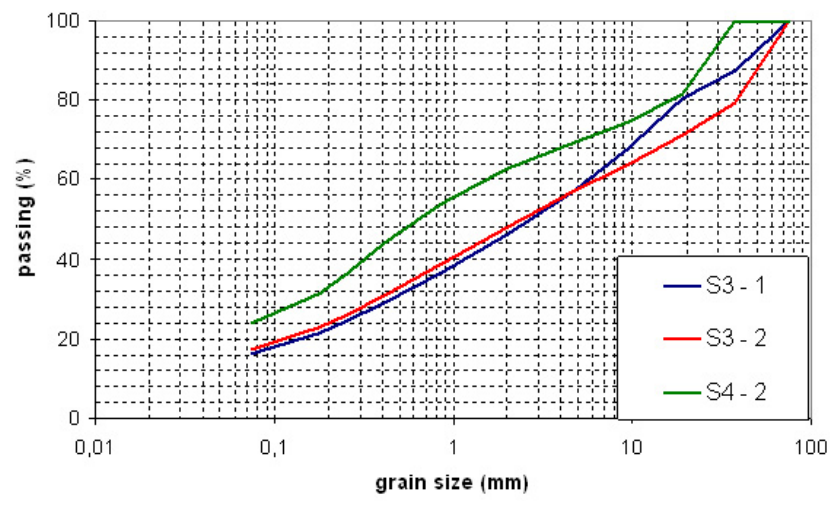

Fig. 7. Grain size distributions of samples taken at shallow depths in the gneissic cover (layer 1).

sonal communication, 2009). The soil is heterogeneous in terms of both grain size distribution and physical properties: the unit weight, $\gamma$, ranges between 15.0 and $20.1 \mathrm{kN} / \mathrm{m}^{3}$, with a mean value of about $16.8 \mathrm{kN} / \mathrm{m}^{3}$; the average dry unit weight, $\gamma_{d}$, is about $15.3 \mathrm{kN} / \mathrm{m}^{3}$; the average water content, $w$, is about $9 \%$. The available grain-size distributions are shown in Fig. 7: the gneissic cover has a low clay and silt portion (approximately less than $24 \%$ ); the sand fraction is between 31 and $39 \%$, and the gravel fraction ranges between 37 and $52 \%$.

The results of the direct shear tests, carried out on the finer portion of the samples, are plotted in terms of shear stress vs. shear displacement (Fig. 8a), and of normal displacement vs. shear displacement (Fig. 8b). The shear behaviour of the gneissic cover is generally ductile and contractive, as expected also at low confining stresses for soils resulting from destructuration of rock associated to weathering phenomena. This is not the case for sample S4-2, which instead exhibits a softening and dilative behaviour as an effect of a higher fraction of clay and silt with respect to the other samples.

The peak shear failure envelope for layer 1 results, according to the Mohr-Coulomb criterion, are characterised by $c_{p}^{\prime}=0$ and $\varphi_{p}^{\prime}=36^{\circ}$ (Fig. 9). Since no laboratory tests on the samples from layer 2 were available, a slightly higher value of the friction angle at peak was assumed for the weathered gneissic bedrock (layer $2 ; \varphi_{p}^{\prime}=38^{\circ}$ ), according to the lower percentage of clay and silt observed in the stratigraphic data (Cascini and Gullà, 1993).

The residual shear parameters were evaluated by considering the results of the direct shear tests on S4-2 sample at shear displacements of about $10 \mathrm{~mm}$ : the residual friction angle which, for soils with low clay fraction, represents the ultimate shear strength without orientation that can be reached at small shear displacements (Lupini et al., 1981) - results to be $\varphi_{r}^{\prime}=32^{\circ}$. This value is consistent with the residual strength values observed by Cascini and Gullà (1993) for samples of gneissic cover nearby the study area. 

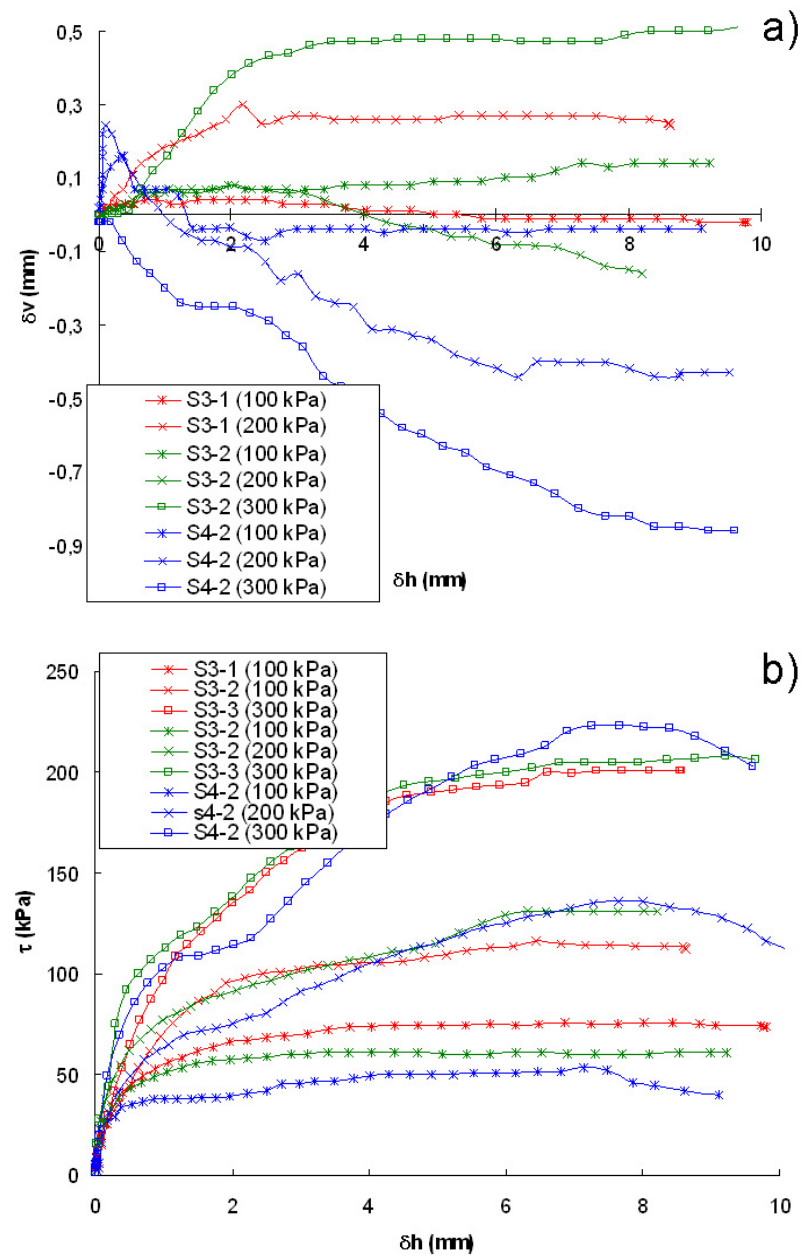

Fig. 8. Results of direct shear tests performed on samples of gneissic cover, expressed in terms of vertical displacement vs. shear displacement (a) and shear stress vs. shear displacement (b).

The landslide mobilizations which occurred during the winters 2008/09 and 2009/10 can be interpreted - perhaps with the only exception of the deepest portion developed inside layer 2 - as a reactivation along pre-existing sliding surfaces. In fact, based on field and borehole evidence, the recent phases of mobilization apparently showed a marked enlarging trend, progressively involving wider and deeper sectors of the slope. Accordingly, in the LEM analyses the adopted shear strength values were those at residual for layer 1 ; on the contrary, the portion of the failure surface inside layer 2 was assumed to be activated for the first time, and a friction angle slightly smaller than the peak value was assumed for layer 2 .

To summarise, the parameters assumed in the backanalysis for the two layers involved in the sliding processes were: $\gamma=17 \mathrm{kN} / \mathrm{m}^{3}, c^{\prime}=0, \varphi^{\prime}=32^{\circ}$ for layer $1 ; \gamma=$ $18 \mathrm{kN} / \mathrm{m}^{3}, c^{\prime}=0, \varphi^{\prime}=36^{\circ}$ for layer 2 . Moreover, as regards the slope material lying above the water table (i.e. in partially

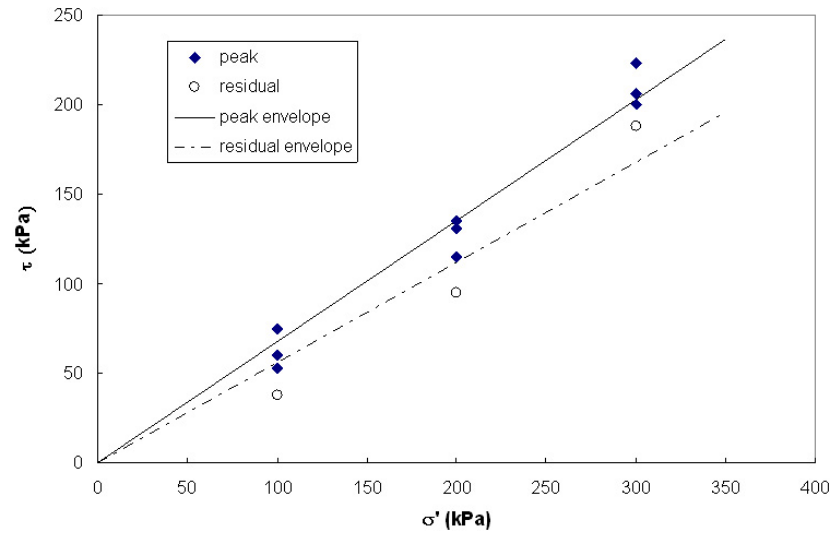

Fig. 9. Peak and residual shear failure envelopes for gneissic cover samples.

saturated conditions), according to the failure criterion valid for partially saturated soils (Fredlund et al., 1978), the values of the unsaturated friction angle, $\varphi_{b}$, were assumed equal to $\varphi^{\prime} / 2$.

In order to define the steady-state groundwater regime of the slope, which can be assumed to be representative of summer flow conditions, a steady-state seepage finite element analysis was carried out; the average of the water table level measurements logged in the $S_{1}$ open-pipe piezometer between June and December 2009 was considered as a reference for the validation of the numerical results. The saturated coefficients of the permeability of the different strata were selected in accordance with the values proposed by Cascini et al. (2006) for similar soils. In particular, the saturated hydraulic conductivity, $k_{\mathrm{sat}}$, for the three layers was assumed equal to: $5 \times 10^{-5}(\mathrm{~m} / \mathrm{s})$ for layer $1 ; 8 \times 10^{-6}(\mathrm{~m} / \mathrm{s})$ for layer $2 ; 8 \times 10^{-7}(\mathrm{~m} / \mathrm{s})$ for layer 3 .

Concerning the partially saturated soils above the water table, a coefficient of permeability constant with suction was assumed for the layers 2 and 3, whereas a variation of the unsaturated coefficient of permeability with suction was taken into account for layer 1. For the latter, the variation of the volumetric water content with suction (soil-water characteristic curve) was estimated based on the grain size curve, according to the method suggested by Arya and Paris (1981); the law of variation of the unsaturated hydraulic conductivity with respect to suction was defined following Green and Corey (1971).

In terms of boundary conditions, an impervious boundary was assigned to the bottom of the mesh, whereas freedraining conditions were prescribed along the slope profile. A constant total head was assumed along both the right- and the left-hand boundaries of the seepage domain: the value of the hydraulic head was set equal to the stream level elevation at the right-hand boundary, whereas it was imposed at an $18 \mathrm{~m}$ depth below the ground level along the left-hand boundary, to comply with the in situ measurements available. 

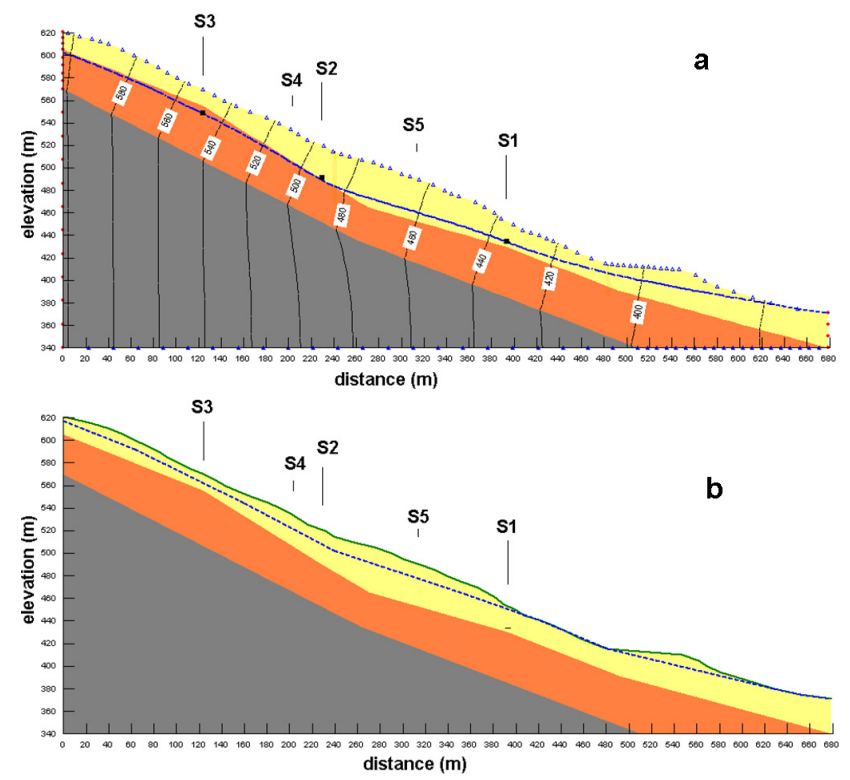

Fig. 10. San Rocco landslide: equipotential lines and water table surface calculated for steady-state seepage regime (a), and maximum raising of water table considered in the parametric analyses (b).

\section{Results}

The seepage analysis indicated a geometry of the water table in good agreement with the in situ measurements taken at $S_{1}$ piezometer, as shown in Fig. 10a: the water table is between 20 and $30 \mathrm{~m}$ below ground level in the upper and middle portions of the slope; it is shallower downslope (10-15 m) and intersects the ground surface just upslope the stream. One vertical section (cf. $S_{1}$ in Fig. 10) was taken into consideration along the slope with respect to the groundwater depth, as reference for the parametric stability analysis: in the cited conditions of steady-state flow regime, the water table results are at a depth of about $19 \mathrm{~m}$ at section $\mathrm{S}_{1}$.

Starting from steady-state regime, a sensitivity LEM study of the different landslide bodies (\#1-6) assumed was performed; for this purpose, different geometries of the water table were considered in order to investigate the critical hydraulic conditions, which may be responsible for the activation of the San Rocco slope movement. The water table depths were not measured during paroxysmal stages of movement. Though, actual piezometric measurements were only taken during the dormant stages of the phenomenon (e.g., summer-fall 2009). As available information on the variation of the water table with time was limited, the water levels considered in the parametric analyses were raised parallel to the summer configuration, the latter being the result from the seepage analysis.

The results of the sensitivity analyses, in terms of factor of stability $\left(F_{i}\right)$ of the six landslide bodies for different groundwater levels, are summarized in Table 3 and in Fig. 11.

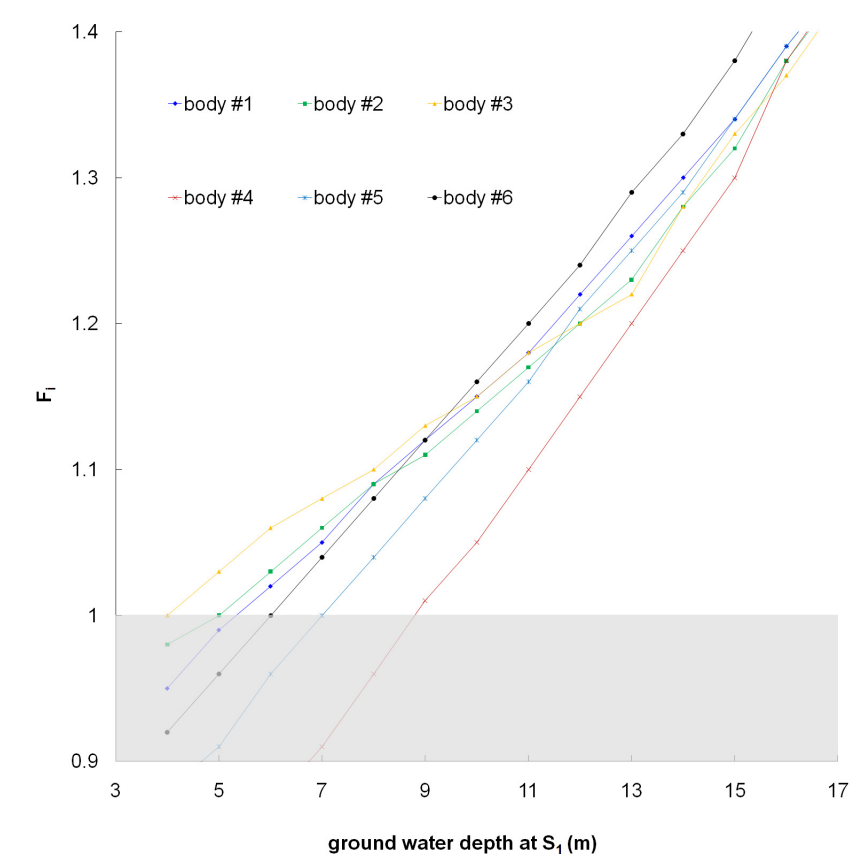

Fig. 11. San Rocco landslide: results of the LEM parametric analysis. Values of $F_{i}$ computed for the six considered landslide bodies in relation to ground water levels at $\mathrm{S}_{1}$ (cf. Table 3 ).

In case of steady-state pore-water pressure regime in the slope, the limit equilibrium analysis suggested quite stable conditions $(F>1.5)$ for all the six landslide bodies considered in this study. The landslide body \#4 becomes unstable when the water table at section $S_{1}$ is at a depth of about $9 \mathrm{~m}$ from the ground level; in such conditions, the water table approximates the ground surface further downslope of $S_{1}$. After a further raise of the water table, the bodies \#5 and \#6 become unstable at depths of 7 and $6 \mathrm{~m}$, respectively. For shallower depths of the water table, the landslide bodies \#1 and \#2 progressively become unstable, followed by \#3. All the considered landslide bodies result in being unstable for a water table depth of $4 \mathrm{~m}$ at $\mathrm{S}_{1}$.

The above results seem in good agreement with in situ evidence observed during the mobilizations which occurred in January 2009 and February 2010. Indeed, clear signs of reactivation of a landslide body referable to \#4 were actually detected in the field a few days before new springs were observed close to $S_{1}$ (cf. Fig. 12). At that time, minor evidence of movements were also detected by the stream, probably due to the activation of a secondary landslide. The landslide body \#5 becomes unstable only after an upward elevation of the water table of about $2 \mathrm{~m}$ in the central and upper part of the slope (cf. Fig. 13). Assuming such hydraulic conditions, the remaining landslide bodies (\#6 and \#1-3) are still stable. After a further rising of the water table of about $1 \mathrm{~m}$, the factor of stability of the landslide body \#6 also reaches unity (cf. Fig. 14). As a matter of fact, the activation of the main landslide body (\#5 and \#6) - observed on both occasions in 
Table 3. Factors of stability $\left(F_{i}\right)$ for the considered landslide bodies (\#1-6), as a function of water table depth below the ground surface (cf. Fig. 11). The minima of $F_{i}$ are in bold (asterisks mark values of $\left.F_{i}<1\right)$. The background colours mark the different levels of alarm, as listed in Table 2.

\begin{tabular}{ccccccc}
$\begin{array}{c}\text { water table depth } \\
(\mathrm{m}) \text { at section } \mathrm{S}_{1}\end{array}$ & $F_{1}$ & $F_{2}$ & $F_{3}$ & $F_{4}$ & $F_{5}$ & $F_{6}$ \\
\hline $\begin{array}{c}19 \\
\text { (steady-state) }\end{array}$ & $\mathbf{1 . 5 2}$ & $\mathbf{1 . 5 2}$ & $\mathbf{1 . 5 2}$ & 1.53 & $\mathbf{1 . 5 2}$ & 1.57 \\
\hline 16 & 1.39 & 1.38 & $\mathbf{1 . 3 7}$ & 1.38 & 1.39 & 1.44 \\
15 & 1.34 & 1.32 & 1.33 & $\mathbf{1 . 3 0}$ & 1.34 & 1.38 \\
14 & 1.30 & 1.28 & 1.28 & $\mathbf{1 . 2 5}$ & 1.29 & 1.33 \\
13 & 1.26 & 1.23 & 1.22 & $\mathbf{1 . 2 0}$ & 1.25 & 1.29 \\
12 & 1.22 & 1.20 & 1.20 & $\mathbf{1 . 1 5}$ & 1.21 & 1.24 \\
11 & 1.18 & 1.17 & 1.18 & $\mathbf{1 . 1 0}$ & 1.16 & 1.20 \\
10 & 1.15 & 1.14 & 1.15 & $\mathbf{1 . 0 5}$ & 1.12 & 1.16 \\
9 & 1.12 & 1.11 & 1.13 & $\mathbf{1 . 0 1}$ & 1.08 & 1.12 \\
8 & 1.09 & 1.09 & 1.10 & $*$ & $\mathbf{1 . 0 4}$ & 1.08 \\
7 & 1.05 & 1.06 & 1.08 & $*$ & $\mathbf{1 . 0 0}$ & 1.04 \\
6 & 1.02 & 1.03 & 1.06 & $*$ & $*$ & $\mathbf{1 . 0 0}$ \\
5 & $*$ & $\mathbf{1 . 0 0}$ & 1.03 & $*$ & $*$ & $*$ \\
4 & $*$ & $*$ & 1.00 & $*$ & $*$ & $*$ \\
\hline
\end{tabular}

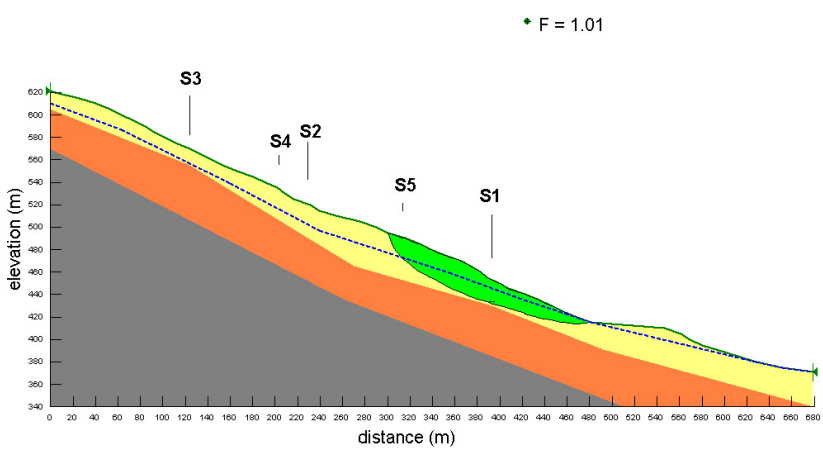

Fig. 12. San Rocco landslide: assumed water table geometry for depth of $9 \mathrm{~m}$ at section $\mathrm{S}_{1}$. For the landslide body \#4, it is $F_{4}=1.01$.

2009 and 2010 after the first mobilization of the middle sector of the slope (\#4) - occurred under exceptional hydraulic conditions, following prolonged rainfalls lasting for about a week. Such rainfalls presumably caused a further increase of the pore pressures even in the uppermost portion of the slope, allowing the activation of the upper sector of the San Rocco landslide.

Based on the results of the LEM parametric analysis, the surveillance system was tentatively refined by including the Factors of Safety $\left(F_{i}\right)$ of the considered landslide bodies among the criteria to be taken into consideration for defining the different levels of alarm. In Table 2, the new criteria are listed, together with a summary of the suggested procedures to be carried out by the municipal technicians, and of the emergency measures that can be adopted by the Civil Protection Authority. The original "criterion", as proposed by Iovine et al. (2009), only referred to maximum punctual velocities.

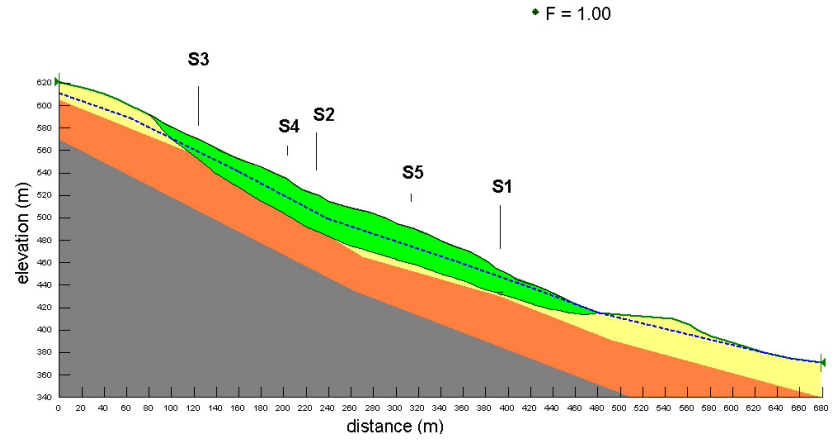

Fig. 13. San Rocco landslide: assumed water table geometry for depth of $7 \mathrm{~m}$ at section $\mathrm{S}_{1}$. For the landslide body $\# 5$, it is $F_{5}=1.00$.

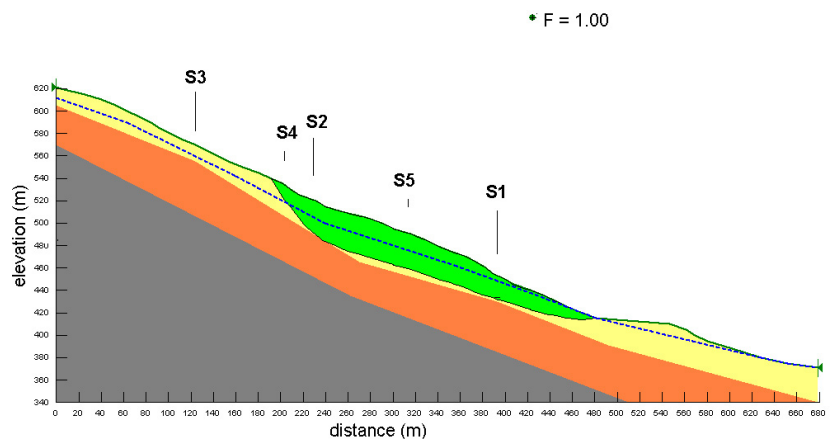

Fig. 14. San Rocco landslide: assumed water table geometry for depth of $6 \mathrm{~m}$ at section $\mathrm{S}_{1}$. For the landslide body $\# 6$, it is $F_{6}=1.00$.

The refined criteria, proposed here, refer to a combination of $F_{i}$ values (and thus, indirectly, to groundwater depths cf. Table 3) and maximum punctual velocities. It should be stressed that, among the computed values of $F_{i}$ for the different bodies (\#1-6), the lowest must be considered for entering Table 2 . The apparent incongruity between $F_{i}>1$ and $v>0$ can be explained by considering that the punctual velocity may be related to local displacements of minor/superficial portions of the slope (and thus, cannot be truly representative of the dynamic of the bodies).

In case a given criterion is met, a warning message is sent to the Mayor (and to the team of consulting experts) via GSM, to allow the activation of suitable actions (e.g., check of specific indicators). Based on the results of field inspections and data processing, the level of alarm can, therefore, be updated.

\section{Conclusions}

As a consequence of the 2010 activation, the middle portion of the San Rocco landslide destroyed the SP.31 and the local roads, and caused the failure of the main infrastructures crossing the unstable area (water system, gas pipeline and power line). The Municipal Administration started realizing remedial works to improve the stability of the slope, aiming 
at reducing the chance of enlargement in the sector above the village. By considering the articulation of the phenomenon, the geomorphologic characteristics of the area, and the type of involved material, the expected evolution of the landslide may be characterised by progressively increasing velocities, up to a "moderate" class (sensu Cruden and Varnes, 1996). Accordingly, the level of risk can be assumed high for the urbanized sector threatened by the landslide, but smaller for the population (which may take advantage of the warning provided by the surveillance system).

As a whole, the analyses confirmed the retrogressive distribution of activity of the San Rocco landslide, as observed in January 2009 and February 2010: when the water table approximates the surface in the middle-lower sector of the slope, an initial stage of activation (body \#4) occurs; this is followed by an upslope activation of the deeper mass (bodies \#5 and \#6), presumably induced by further increase of the water table.

Since the beginning of each mobilization of the San Rocco landslide, new springs were observed in the middle-lower sector of the slope, whereas those already existing showed a notable increase of flow rate. The initial stage was followed by a gradual activation of the uppermost portion of the slope: in this sector, clear signs of enlargement - even more accentuated on 2010 activation with respect to 2009 - were recognized toward the historical centre, on the left, and the cemetery, on the right.

To manage the mentioned emergencies, the Mayor of SBU took advantage of the information collected by means of the integrated surveillance system, and of the provisional procedures, empirically suggested in the early stages of the 2009 landslide activation. Direct field observations and in situ measurements of significant parameters constituted the core of the surveillance system initially implemented at SBU.

In the present study, based on geohydrological and geotechnical analyses, a more physical approach was adopted - although still on a preliminary basis - to evaluate the stability conditions of the slope and the hierarchy of the different landslide bodies to reach instability. As the response of water level to rainfalls is still poorly understood for the study case, due to the limited extent of the observation period, the LEM analyses were performed in terms of a parametric study in order to investigate the sensitivity of slope stability to groundwater level variations. Further field investigations will be carried out at the end of the present phase of mobilization, and the ADs will be updated by relocating/installing instruments. In addition, a hydrological modelling aimed at evaluating the critical rainfalls capable of activating the San Rocco landslide has also been recently carried out by Capparelli and co-authors (2010). In particular, starting from historical dates of activation and rain data, the hydrological model has been calibrated against the observed triggering events; as a result, the main acceleration phases of the landslide, as recorded at surface by the ADs, could be properly predicted, thus validating the procedure.
The LEM results provided useful indications to refine the procedures for landslide risk management. In particular, assuming that water levels can directly be measured at a number of significant places by means of a continuous monitoring system (even better, if coupled with the measurement of superficial and/or deep displacements), the behaviour of the landslide might be predicted. According to the current knowledge of the case study, results suggest that groundwater depths at $S_{1}$ ranging from 15 to $9 \mathrm{~m}$ roughly correspond to a factor of safety between 1.3 and 1.0 for the landslide body \#4 - i.e. the sector between the local road to the cemetery and the SP.31, which actually showed the highest tendency to mobilization in recent times.

Based on the preliminary LEM results, the original set of emergency procedures was tentatively refined, by linking the levels of alarm to the predicted values of the factor of safety, this latter depending on the groundwater levels observed at $S_{1}$. Indeed, further investigations are still needed to better define the relationships between rainfalls, piezometric levels and factors of stability of the San Rocco landslide. In the near future, the emergency system at SBU will be conditioned to such type of information - as well as to the results of the cited hydrological modelling - aiming at founding the procedures on a less empirical basis.

Acknowledgements. This study was partly funded by the Administration of San Benedetto Ullano, which also made available the results of explorative drillings realized in the area of interest. The in situ monitoring system was implemented by the Advanced Devices S. p. A. The authors thank the referees and the handling editor for their constructive comments and suggestions.

Edited by: M. Pastor

Reviewed by: two anonymous referees

\section{References}

Amodio-Morelli, L., Bonardi, G., Colonna, V., Dietrich, D., Giunta, G., Ippolito, F., Liguori, V., Lorenzoni, S., Paglionico, A., Perrone, V., Piccarreta, G., Russo, M., Scandone, P., Zanettin Lorenzoni, E., and Zuppetta, A.: L'arco calabro-peloritano nell'orogene appenninico-maghrebide, Mem. Soc. Geol. Ital., 17, 1-60, 1976 (in Italian).

Anderson, M., Holcombe, L., Flory, R., and Renaud, J.-P.: Implementing low-cost landslide risk reduction: a pilot study in unplanned housing areas of the Caribbean, Nat. Hazards, 47, 297315, 2008.

Arya, L. M. and Paris, J. F.: A physicoempirical model to predict soil moisture characteristics from particle-size distribution and bulk density data, Soil Sci. Soc. Am. J., 45, 1023-1030, 1981.

Azimi, C., Biarez, J., Desvarreux, P., and Keime, F.: Prévision d'éboulement en terrain gypseux, edited by Bonnard, C., Landslides, Proc. 5th Int. Symp. on Landslides, Lausanne, Balkema, Rotterdam, 531-536, 1988 (in French).

Bishop, A. W.: The use of the slip circle in the stability analysis of slopes, Geotechnique, 5(1), 7-17, 1955. 
Campbell, R. H.: Soil Slips, Debris Flows, and Rainstorms in the Santa Monica Mountains and Vicinity, Southern California, US Geological Survey, Reston, VA., USGS Professional Paper 851, 1975.

Capparelli, G., Iaquinta, P., Iovine, G. G. R., Terranova, O. G., and Versace, P.: Modelling the rainfall-induced mobilization of a large slope movement in northern Calabria, Nat. Hazards, in press, doi:10.1007/s11069-010-9651-1, 2010.

Carrara, A., Catalano, E., Sorriso-Valvo, G. M., Reali, C., Merenda, L., and Rizzo, V.: Landslide morphometry and typology in two zones, Calabria, Italy, B. Eng. Geol. Environ., 16(1), 8-13, 1977.

Carrara, A., Merenda, L., Nicoletti, P. G., and Sorriso-Valvo, G. M.: Slope instability in Calabria, Italy, in: Proc. of the PolishItalian Seminar on Superficial Mass Movement in Mountain Regions, Szymbark, May 1979, Instit. Meteor. i Gospod. Wodnej, Warszawa, 47-62, 1979.

Cascini, L. and Gullà, G.: Caratterizzazione fisico-meccanica di terreni prodotti dall'alterazione di rocce gneissiche, Riv. It. Geotec., 2-93, 125-147, 1993 (in Italian).

Cascini, L., Critelli, S., Di Nocera, S., Gullà, G., and Matano, F.: Weathering and landsliding in Sila Massif gneiss (Northern Calabria, Italy), in: Proc. 7th International IAEG Congress, Lisboa, Portugal, 1613-1622, 1994.

Cascini, L., Gullà, G., and Sorbino, G.: Groundwater modelling of a weathered gneissic cover, Can. Geotech. J., 43(11), 1153-1166, 2006.

CASMEZ, Carta Geologica della Calabria, F.229IIINE "Lattarico" (in scale 1/25000), Poligrafica \& CarteValori, Ercolano, Napoli, Italy, 1967 (in Italian).

Crescenzi, E., Grassi, D., Iovine, G., Merenda, L., Miceli, F., and Sdao, F.: Fenomeni di instabilità franosa nei centri abitati calabri: esempi rappresentativi, Geol. Appl. e Idrogeol., 31, 203226, 1996 (in Italian).

Cruden, D. M. and Varnes, D. J.: Landslide Types and Processes, edited by: Turner, A. K. and Schuster, R. L., Landslides: Investigation and Mitigation, Special Report 247, Transportation Research Board, National Research Council, National Academy Press, Washington DC, 36-75, 1996.

Dai, F. C., Lee, C. F., and Ngai, Y. Y.: Landslide risk assessment and management: an overview, Eng. Geol., 64, 65-87, 2002.

Duncan, M.: State-of-the-art: static stability and deformation analysis. Stability and performance of slopes and embankmentsII, ASCE- Geotech Eng Div Special Publication, 31, 222-266, 1992.

Fell, R., Hungr, O., Leroueil, S., and Riemer, W.: Keynote paper - Geotechnical engineering of the stability of natural slopes and cuts and fills in soil, in: Proc. GeoEng2000, Int. Conf. on Geotechnical and Geol. Eng., Melbourne, Australia, Technomic Publishing, Lancaster, 1, 21-120, 2000.

Ferrari, E., Iovine, G., and Petrucci, O.: Evaluating landslide hazard through geomorphologic, hydrologic and historical analyses in North-Eastern Calabria (southern Italy), in: Proc. EGS Plinius Conference Mediterranean Storms, Maratea, Italy, October 1999, Editoriale Bios, Cosenza, Italy, 425-438, 2000.

Fredlund, D. G., Morgenstern, N. R., and Widger, R. A.: The shear strength of unsaturated soils, Can. Geotech. J., 15, 313-321, 1978.

Green, R. E and Corey, J. C.: Calculation of hydraulic conductivity: a further evaluation of some predictive methods, Soil Sci. Soc.
Am. Proc., 35, 3-8, 1971.

Guzzetta, G.: Ancient tropical weathering in Calabria, Nature, 5473, 302-303, 1974.

Guzzetti, F.: Landslides fatalities and the evaluation of landslide risk in Italy, Eng. Geol., 58, 89-107, 2000.

Iovine, G. and Merenda, L.: Nota illustrativa alla "Carta delle frane e della mobilizzazione diastrofica, dal 1973 ad oggi, nel bacino del Torrente Straface (Alto Jonio, Calabria)", Geol. Appl. e Idrogeol., 31, 107-128, 1996 (in Italian).

Iovine, G., Parise, M., and Tansi C.: Slope movements and tectonics in North-Eastern Calabria (Southern Italy), Proc. 7th Int. Symp. on Landslides, ISL'96, "Landslides - Glissements de terrain", The Norwegian Institute of Technology, 17-21 June (Trondheim, Norvegia), editey by: Balkema, A. A., Rotterdam/Brookfield, 2, 785-790, 1996.

Iovine, G. and Petrucci, O.: Effetti sui versanti e nel fondovalle indotti da un evento pluviale eccezionale nel bacino di una fiumara calabra (T. Pagliara), Boll. Soc. Geol. It., 117, 821-840, 1998 (in Italian).

Iovine, G., Petrucci, O., Rizzo, V., and Tansi, C.: The March 7th 2005 Cavallerizzo (Cerzeto) landslide in Calabria - Southern Italy, in: Proc. IAEG Conference, Nottingham, Conference CD, IAEG2006 Paper number 785, The Geological Society of London, 2006.

Iovine, G., Iaquinta, P., and Terranova, O.: Emergency management of landslide risk during autumn-winter 2008/2009 in Calabria (Italy), The example of San Benedetto Ullano, editey by: Anderssen, R. S., Braddock, R. D., and Newham, L. T. H., Proc. 18th World IMACS Congr. and MODSIM09 Int. Congr. on Modelling and Simulation, 2686-2693, 2009.

Janbu, N.: Application of composite slip surfaces for stability analysis. In: Proc. European Conf. on Stability of Earth Slopes, Stockholm, 3, 43-49, 1954.

Lupini, J. F., Skinner, A. E., and Vaughan, P. R.: Drained residual strength of cohesive soils, Geotechnique, 31(2), 181-213, 1981.

Monaco, C. and Tortorici, L.: Active faulting in the Calabrian arc and eastern Sicily, J. Geodyn., 29, 407-424, 2000.

Morgenstern, N. R. and Price, V. E.: The analysis of the stability of general slip surfaces, Geotechnique, 15, 79-93, 1965.

Morgenstern, N. R.: Keynote paper: The role of analysis in the evaluation of slope stability, in: Proc. 6th International Symposium of Landslides, Christchurch, New Zealand, Balkema, 1615-1629, 1992.

Oboni, F.: General Report: Analysis methods and forecasting of behaviour, edited by: Bonnard, C., Landslides. Proc. 5th Int. Symp. on Landslides, Lausanne, Balkema, Rotterdam, 491-499, 1988.

PAI: Piano Stralcio di Bacino per l'Assetto Idrogeologico (PAI), Autorità di Bacino Regionale, Regione Calabria, 2001 (in Italian).

Ramesh, M. V.: Real-time Wireless Sensor Network for Landslide Detection, in: Third Int. Conf. on Sensor Technologies and Applications. SENSORCOMM 2009, Athens/Glyfada, Greece, 1823 June 2009, 405-409, 2009.

Salt, G.: Landslide mobility and remedial measures, edited by: Bonnard, C., Landslides. Proc. 5th Int. Symp. on Landslides, Lausanne, Balkema, Rotterdam, 757-770, 1988.

Sarma, S. K.: Stability analysis of embankments and slopes, Geotechnique, 23(3), 423-433, 1973.

Sorriso-Valvo, G. M.: Mass movements and slope evolution in 
Calabria. In: 4th Int. Conf. and Field Workshop on Landslides, Tokyo, 23-30, 1985.

Sorriso-Valvo, G. M.: The geomorphology of Calabria - a sketch, Geogr. Fis. Din. Quat., 16(1), 75-80, 1993.

Spencer, E.: A method of analysis of the stability of embankments assuming parallel inter-slice forces, Geotechnique, 17(1), 11-26, 1967.

Tansi, C., Talarico, A., Iovine, G., Folino Gallo, M., and Falcone, G.: Interpretation of radon anomalies in seismotectonic and tectonic-gravitational setting of the south-eastern Crati Graben (Northern Calabria, Italy), Tectonophysics, 396(3-4), 181-193, 2005 .
Tansi, C., Muto, F., Critelli, S., and Iovine, G.: Neogene-Quaternary strike-slip tectonics in the central Calabrian Arc (Southern Italy), J. Geodyn., 43(3), 393-414, 2007.

Tran vo Nhiem, J., Guilloux, A., and D'Apolito, P.: Analyse et suivi d'un grand glissement de versant dans les Andes colombiennes, edited by: Bonnard, C., Landslides. Proc. 5th Int. Symp. on Landslisdes, Lausanne, Balkema, Rotterdam, 783-788, 1988 (in French).

Versace, P., Ferrari, E., Gabriele, S., and Rossi, F.: Valutazione delle piene in Calabria, Geodata, 30, CNR IRPI-GNDCI, Cosenza, Italy, 1989 (in Italian). 